\title{
Using an Integrated Persistence Model to Predict College Graduation
}

\author{
Liuli Huang ${ }^{1}$, Lahna R. Roche ${ }^{2}$, Eugene Kennedy ${ }^{1} \&$ Melissa B. Brocato ${ }^{2}$ \\ ${ }^{1}$ College of Human Sciences \& Education, Louisiana State University, Baton Rouge, Louisiana, USA \\ ${ }^{2}$ Center for Academic Success, Louisiana State University, Baton Rouge, Louisiana, USA \\ Correspondence: Liuli Huang, College of Human Sciences \& Education, Louisiana State University, 335 Peabody \\ Hall, Baton Rouge, LA 70803, USA. Tel: 1-225-328-5602
}

Received: April 13, 2017

Accepted: May 5, 2017

Online Published: May 9, 2017

doi:10.5430/ijhe.v6n3p40

URL: https://doi.org/10.5430/ijhe.v6n3p40

\begin{abstract}
Many researchers have explored the relationships between the likelihood of graduating from college and demographic and pre-college factors such as gender, race/ethnicity, high school grade point average (GPA), and standardized test scores. However, additional factors such as a student's college major, home address, or use of learning support in college have been examined to a far lesser degree. This study seeks to add these factors to an integrative persistence model in order to examine their impact on predicting college graduation in a six-year timeframe. Results indicate that students with in-state home addresses are more likely to graduate within six years than students with out-of-state home addresses, when controlling for other factors. Findings also suggest that graduation rates vary considerably for different majors and for those using learning support such as tutoring and Supplemental Instruction in college. Therefore, these additional factors become important for institutions to consider, particularly as it applies to implementing new programs, expanding programs proven effective, and/or targeting specific populations of students in order to help them persist to timely college graduation.
\end{abstract}

Keywords: College graduation, Predicting graduation, Home address, Majors, Learning support, Tutoring, Supplemental Instruction

\section{Introduction}

\subsection{Purpose}

There is no denying the importance of college graduation rates for both higher educational institutions and students themselves. This important data point may affect processes and outcomes associated with accreditation, funding, and national rank for institutions. Similarly, differences in graduation rates may play a prominent role in the college selection decisions made by prospective students and their families. Therefore, many researchers have explored demographic factors, pre-college factors, and sociological factors to determine if specific influences impact college graduation rates. The purpose of this study is to investigate additional factors, including college major, student's home address, and student's use of learning support, to determine how these factors impact a student's likelihood of graduating from college within six years.

\subsection{Theoretical Framework}

Two mainstream approaches have been used to examine college student persistence, sociological and economic approaches (John, Cabrera, Nora, \& Asker, 2000; Perna, 1998). For the purpose of this study, the sociological approach will be used. The sociological approach predicts college student persistence based on factors related to students' social and academic integration (Tinto, 1975). This study will examine typical social factors, but will consider additional factors. Social factors that will be examined include demographic characteristics and student's home address, while academic factors include both pre-college (i.e., high school GPA) and college (i.e., first year GPA, college major) variables.

\subsubsection{Demographic Characteristics}

Demographic characteristics used for this project include gender, race/ethnicity, and first-generation status. Gender is important to consider when discussing the likelihood of graduating from college, since women currently constitute the majority of students earning baccalaureate degrees at four years and six years (Flashman, 2013; Mattern \& Marini, 2014). Race/ethnicity is also important as more institutions are serving minority populations (Fischer, 2007; Flores \& Park, 2013). Evidence shows that minority students, including Blacks/African Americans, 
Hispanics/Latinos, and Native Americans/American Indians are less likely to graduate from college (Richardson Jr \& de los Santos Jr, 1988; Wagner, 2015), and their graduation rates are substantially lower than white students (Zwick \& Sklar, 2005). Moreover, Black/African American and Hispanic/Latino students are more likely to come from low income backgrounds and to be first-generation students (Fischer, 2007). The final demographic characteristics factor discussed in this study is first-generation status. A first-generation student is typically defined as a student whose parents have not completed college by earning a baccalaureate degree (Ishitani, 2006; Petty, 2014). First-generation students are in a disadvantageous position for college success and completion due to characteristics such as family and/or work responsibilities, financial difficulties, and lower academic preparation (IHEP, 2012; Ishitani, 2006) and may require creative approaches to help motivate them in college (Petty, 2014).

\subsubsection{Pre-college and College Factors}

Pre-college factors discussed in this study include students' high school GPA and ACT math scores. Most studies indicate a strong positive relationship between high school GPA, standardized test scores and probability of graduation (Radunzel \& Noble, 2012; Zwick \& Sklar, 2005). High school GPA is a primary admission criteria and has been determined to be the "most important factor" for college admission (Breland, Maxey, Gernand, Cumming, $\&$ Trapani, 2002). Yet, findings from previous research indicates that high school performance and standardized test scores only account for a minimal amount of variance (25-29\%) on college performance (Kuh, Cruce, Shoup, Kinzie, \& Gonyea, 2008; Wolfe \& Johnson, 1995) while first year college GPA "represents a substantial improvement in prediction" (DeBerard, Spielmans, \& Julka, 2004).

While many studies have examined student gender, race, income, pre-college preparation, and high school GPA as predictors of retention and graduation from 4-year institutions (Attewell, Heil, \& Reisel, 2011; Mettler, 2011; Reason, 2003), far less research has examined factors such as student majors or home address. These factors, along with student use of college learning support, play an important role in college and early research suggest some interesting findings. Habley and Mcclanahan (2004) determined that retention programs such as academic advising, first-year programs, and learning support make the greatest impact at 4-year public institutions. In recent years, learning centers have taken center stage in offering quality academic resources and learning support for students, such as tutoring and Supplemental Instruction. Therefore, this study will include these rarely discussed yet important factors and incorporate the use of resources in order to validate the benefit of learning support for student success.

An integrative approach is a suitable approach to explore the relationship between multiple predictors and the target variable. The target variable in this study is college graduation status, specifically whether or not students graduate from college within six years. Following the integrative approach, this study examines college graduation rates as a function of sociological factors, but also examines rarely discussed variables. The additional variables include student college major, home address (in-state and out-of-state), and use of learning support in college (tutoring and Supplemental Instruction). The model used in this study is shown in Figure 1. 


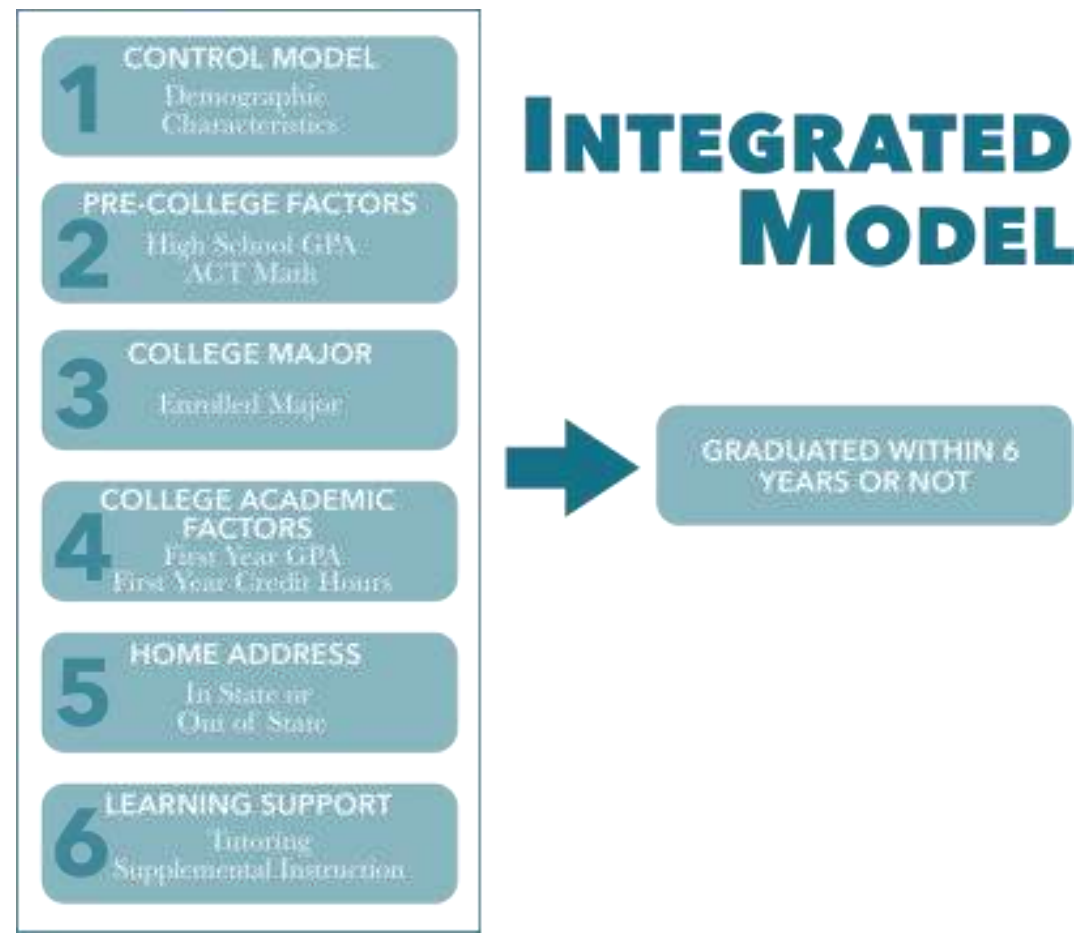

Figure 1. Integrative Persistence Model

\section{Method}

\subsection{Participants}

The participants in this study are first time, full-time freshman undergraduate students ( $\mathrm{N}=8259)$ from a public, 4-year institution, beginning their study in the 2009 fall semester ( $\mathrm{N}=4241)$, and the 2010 fall semester ( $\mathrm{N}=4018$ ). For the purposes of this project, the institution is referred to as State University.

\subsection{Procedures}

The dependent variable is graduation status, whether a student graduates within six years or not. Students who graduated within six years are coded as 1 and students who did not graduate within six years are coded as 0 . The logistic regression models predict the likelihood that a student will graduate within six years. Descriptive statistics are provided in Table 1.

Independent variables include demographic characteristics, pre-college factors, college major, college academic factors, home address (in-state versus out-of-state) and the use of learning support, specifically tutoring (TU) and Supplemental Instruction (SI). Student demographic characteristics include gender, race/ethnicity, and first-generation status.

For gender, male students are coded as 0 and female students are coded as 1 . Regarding race/ethnicity, students identified as white are coded as 1, while any students identified as Black or African American, Hispanic or Latino, or American Indian/Alaska Native are coded as 0. For the variable related to first-generation, first-generation students are coded as 1, and non-first-generation students are coded as 0. Similar compositions are reflected in both the 2009 and 2010 cohorts, whereby statistics show that gender is nearly evenly distributed $(54 \%$ and $52 \%$ females, respectively), the majority of students are white ( $88 \%$ and $87 \%$, respectively), and about a quarter of students are first-generation (26\% and 23\%, respectively). 
Table 1. Descriptive Statistics

Variable

\section{Dependent Variable}

Graduated within 6 years

\section{Demographic Characteristics}

Gender*

Female

Male

First Generation*

Yes

No

Race*

White

OtherThree

\section{Pre-College Factors}

High school GPA

ACT math

\section{College Major}

Majors and the corresponding code*

Science $=1$

Engineering=2

Business $=3$

Education $=4$

Humanities \& Social Sciences=5

Art=6

Communication $=7$

\section{College Academic Factors}

First year GPA

First year credit hours

\section{Home Address}

In state or out of state*

In state

Out of state

\section{Learning Support}

Supplemental Instruction=1

Supplemental Instruction $=0$

Tutoring=1

Tutoring $=0$

\section{Fall Sample}

Frequency or Mean $\underline{\text { Graduate within } 6 \text { years }}$

Frequency or Mean
2009 Fall

$4241(64 \%)$

2010 Fall

$4018(64 \%)$

$54 \%$

$46 \%$

$26 \%$

$88 \%$

$12 \%$

3.37

22.38

$996(23.5 \%)$

$765(18 \%)$

$420(9.9 \%)$

$259(6.1 \%)$

$597(14.1 \%)$

$264(6.2 \%)$

$270(6.4 \%)$

2.76

$52 \%$

$48 \%$

$23 \%$

2009 Fall

2010 Fall 


\section{Results}

\subsection{Analysis}

Two multivariate logistic regression models were conducted to assess a student's likelihood of graduating from college within six years. Altogether there were six models with one group of variables added each time to enable exploration of each category of variables. Model 1 is the control model, accounting for basic demographic factors only - gender, race/ethnicity, and first-generation status. Model 2 included the Model 1 variables and additional variables related to pre-college academic factors - high school GPA and ACT math score.

The variable specifying college major was added into Model 3. With more than 100 college majors at State University, seven groups were created, categorized based on academic colleges. These were coded from 1 to 7; hence, the variable college major is considered categorical. College majors with extremely small sample sizes were deleted from the dataset.

College academic factors, including first-year GPA, and the number of first-year credit hours earned, were added into Model 4. Student's home address, in-state versus out-of-state, was added into Model 5. For this study, in-state referred to student's whose home address was in the same state as State University and out-of-state referred to those with a home address outside of that state. The purpose of this model is to determine if students' home addresses impact their likelihood of graduating from college. Students with in-state home addresses are coded as 1 and those with out-of-state home addresses are coded as 0 .

Finally, a student's use of college learning support, specifically tutoring and Supplemental Instruction, was added into Model 6. The purpose of this model is to examine whether students who use these academic resources benefit from timely graduation in college.

Values of pseudo-R-square statistics, coefficient estimates, odds ratios (OR), and the percentage correct from logistic regression are provided and discussed for each of the six models. Pseudo-R-square is used to assess the degree to which the independent variables are effective at predicting the target variable. The higher the pseudo-R-square value is, the better the model fits the data. The coefficient estimates indicate the significance of each independent variable to the model. The odds ratio is the odds of a student graduating within six years to the odds of a student not graduating within six years. Odds ratios greater than (less than) one are associated with a higher (lower) likelihood that a student will graduate within six years. The percentage correct in the classification tables provides the percentage of correct and incorrect estimates for each of the models. The percentage correct increased gradually from Model 1 to Model 6. The details are provided in Tables 14 to 19 in the appendix.

\subsection{Models}

\subsubsection{Model 1: Demographic Characteristics}

The demographic factors, including gender, race/ethnicity, and first-generation status, play the role of the control model in this study. The pseudo-R-square for the year 2009 and year 2010 groups are 0.017 and 0.021 , respectively. It is understandable that the pseudo-R-square values are very small because it is difficult to predict a student's academic success using demographic factors alone. Table 3 provides the details of each variable in the model. Wald measures the significance of each variable in its ability to contribute to the model. The $\operatorname{Exp}(B)$ is the odds ratio for each variable. An $\operatorname{Exp}(B)$ value greater than 1 represents the increase in odds, and an $\operatorname{Exp}(B)$ value less than 1 represents a decrease.

In general, the demographic characteristics are consistent for the 2009 and 2010 cohorts in the first model. However, there are slight differences when examining the two groups in more details. For the 2009 group, only the variable of first-generation status is statistically significant. Gender and race/ethnicity do not significantly impact the likelihood of graduating from college. For the 2010 group, all the variables are statistically significant. But for both groups, first-generation status has a strong negative impact on the probability of graduating from college. Therefore, being considered a first-generation student significantly decrease the likelihood ( 0.547 and 0.559 times, respectively) of graduating from college.

Consistent when controlling for other differences, being a female increases the likelihood (1.133 and 1.317 times, respectively) of graduating from college within six years. Regarding race/ethnicity, for the 2009 group, when controlling for the difference of other variables, being a white student has the same likelihood (1.000) of graduating from college as being any one of the other three races/ethnicities; yet, for the 2010 group, being white increases the likelihood (by 1.460 times) of graduating from college. 
Table 2. Model 1 Summary

\begin{tabular}{ccccc}
\hline ENTRY_TERM & Step & $\begin{array}{c}-2 \text { Log } \\
\text { likelihood }\end{array}$ & $\begin{array}{c}\text { Cox \& Snell R } \\
\text { Square }\end{array}$ & $\begin{array}{c}\text { Nagelkerke R } \\
\text { Square }\end{array}$ \\
\hline 2009 & 1 & 3885.060 & .017 & .023 \\
2010 & 1 & 4133.363 & .021 & .030
\end{tabular}

Table 3. Demographic Characteristics

\begin{tabular}{llllllll}
\hline ENTRY_TERM & B & S.E. & Wald & df & Sig. & Exp(B) \\
\hline \multirow{2}{*}{2009} & FIRST_GE0_FLAG & -.603 & .085 & 50.157 & 1 & .000 & .547 \\
& White_OtherThree & .000 & .119 & .000 & 1 & .999 & 1.000 \\
& GENDER & .125 & .077 & 2.593 & 1 & .107 & 1.133 \\
& Constant & .801 & .126 & 40.487 & 1 & .000 & 2.227 \\
& & & & & & & \\
\multirow{2}{*}{2010} & FIRST_GE0_FLAG & -.582 & .087 & 44.674 & 1 & .000 & .559 \\
& White_OtherThree & .378 & .111 & 11.589 & 1 & .001 & 1.460 \\
& GENDER & .275 & .075 & 13.494 & 1 & .000 & 1.317 \\
& Constant & .408 & .115 & 12.670 & 1 & .000 & 1.504 \\
\hline
\end{tabular}

\subsubsection{Model 2: Pre-College Factors}

The second model examines pre-college factors and is comprised of high school GPA and ACT math score. The details can be seen in Table 5. The pre-college factors add explanatory power to the overall model as indicated by a statistically significantly increase (241\% and $186 \%$, respectively) in pseudo-R-square (R-square $=0.058$ and 0.060 , respectively). Adding the pre-college factors does not impact the demographic characteristics much. After controlling for other factors, for every one-unit increase in the high school GPA, the likelihood of graduating from college within six years increases significantly (by 3.18 and 2.850 times, respectively). However, in this analysis, the ACT math score does not show a significant impact. Model 2 is consistent for both groups.

Table 4. Model 2 Summary

\begin{tabular}{ccccc}
\hline ENTRY_TERM & Step & -2 Log likelihood & $\begin{array}{c}\text { Cox \& Snell R } \\
\text { Square }\end{array}$ & $\begin{array}{c}\text { Nagelkerke R } \\
\text { Square }\end{array}$ \\
\hline 2009 & 1 & 3751.074 & .058 & .080 \\
2010 & 1 & 3994.943 & .060 & .083 \\
\hline
\end{tabular}

Table 5. Pre-college Factors

\begin{tabular}{llllllll}
\hline ENTRY_TERM & B & S.E. & Wald & df & Sig. & Exp(B) \\
\hline \multirow{2}{*}{2009} & FIRST_GE0_FLAG & -.620 & .087 & 50.562 & 1 & .000 & .538 \\
& White_OtherThree & -.129 & .122 & 1.105 & 1 & .293 & .879 \\
& GENDER & -.021 & .081 & .070 & 1 & .791 & .979 \\
& HS_ACAD_AVG & 1.157 & .106 & 118.004 & 1 & .000 & 3.180 \\
& ACT_MATH & .001 & .005 & .034 & 1 & .853 & 1.001 \\
& Constant & -2.910 & .352 & 68.370 & 1 & .000 & .054 \\
& & & & & & & \\
& FIRST_GE0_FLAG & -.603 & .089 & 45.764 & 1 & .000 & .547 \\
& White_OtherThree & .251 & .115 & 4.814 & 1 & .028 & 1.286 \\
& GENDER & .142 & .078 & 3.299 & 1 & .069 & 1.153 \\
& HS_ACAD_AVG & 1.047 & .103 & 103.796 & 1 & .000 & 2.850 \\
& ACT_MATH & .013 & .005 & 6.012 & 1 & .014 & 1.013 \\
& Constant & -3.207 & .341 & 88.257 & 1 & .000 & .040 \\
\hline
\end{tabular}




\subsubsection{Model 3: College Major}

College major is included in the third model. This model also adds significant explanatory value to the model by an increase of $33 \%$ and $37 \%$ (R-squares $=0.077$, and 0.082 respectively). The details can be seen in Table 7. The college major factor is categorical and significant for both groups. After controlling for other factors in the model, the likelihood of graduating from college increased gradually from major to major for the 2009 and 2010 cohorts. The results were significant with slight changes in the order of those majors that fell in the middle but consistent for majors that fell at the high and low ends. For both cohorts, the likelihood of graduating in communications was highest and the likelihood of graduating in science and engineering was lowest, indicating that students majoring in science, technology, engineering, and math (STEM) disciplines are less likely to graduate.

Table 6. Model 3 Summary

\begin{tabular}{ccccc}
\hline ENTRY_TERM & Step & $\begin{array}{c}-2 \text { Log } \\
\text { likelihood }\end{array}$ & $\begin{array}{c}\text { Cox \& Snell R } \\
\text { Square }\end{array}$ & $\begin{array}{c}\text { Nagelkerke R } \\
\text { Square }\end{array}$ \\
\hline 2009 & 1 & 3065.282 & .077 & .108 \\
2010 & 1 & 3643.260 & .082 & .116 \\
\hline
\end{tabular}

Table 7. College Majors

\begin{tabular}{|c|c|c|c|c|c|c|c|}
\hline \multicolumn{2}{|c|}{ ENTRY_TERM } & \multirow{2}{*}{$\frac{B}{-.579}$} & \multirow{2}{*}{$\begin{array}{l}\text { S.E. } \\
.097\end{array}$} & \multirow{2}{*}{$\frac{\text { Wald }}{35.629}$} & \multirow{2}{*}{$\frac{\mathrm{df}}{1}$} & \multirow{2}{*}{$\begin{array}{l}\text { Sig. } \\
.000\end{array}$} & \multirow{2}{*}{$\frac{\operatorname{Exp}(\mathrm{B})}{.560}$} \\
\hline & FIRST_GE0_FLAG & & & & & & \\
\hline & White_OtherThree & -.231 & .135 & 2.920 & 1 & .087 & .794 \\
\hline & GENDER & -.042 & .098 & .189 & 1 & .664 & .958 \\
\hline & HS_ACAD_AVG & 1.341 & .121 & 122.069 & 1 & .000 & 3.824 \\
\hline & ACT_MATH & .001 & .006 & .028 & 1 & .866 & 1.001 \\
\hline & Major & & & 46.139 & 6 & .000 & \\
\hline \multirow[t]{13}{*}{2009} & Major(1) & -1.097 & .202 & 29.492 & 1 & .000 & .334 \\
\hline & Major(2) & -.919 & .213 & 18.678 & 1 & .000 & .399 \\
\hline & Major(3) & -.655 & .223 & 8.669 & 1 & .003 & .519 \\
\hline & Major(4) & -.622 & .244 & 6.504 & 1 & .011 & .537 \\
\hline & Major(5) & -.566 & .211 & 7.213 & 1 & .007 & .568 \\
\hline & Major(6) & -.288 & .251 & 1.309 & 1 & .253 & .750 \\
\hline & Constant & -2.643 & .426 & 38.398 & 1 & .000 & .071 \\
\hline & FIRST_GE0_FLAG & -.617 & .094 & 42.801 & 1 & .000 & .540 \\
\hline & White_OtherThree & .297 & .120 & 6.135 & 1 & .013 & 1.346 \\
\hline & GENDER & .145 & .087 & 2.804 & 1 & .094 & 1.156 \\
\hline & HS_ACAD_AVG & 1.221 & .110 & 123.159 & 1 & .000 & 3.389 \\
\hline & ACT_MATH & .016 & .005 & 8.882 & 1 & .003 & 1.016 \\
\hline & Major & & & 52.947 & 6 & .000 & \\
\hline \multirow[t]{7}{*}{2010} & Major(1) & -.932 & .188 & 24.596 & 1 & .000 & .394 \\
\hline & Major(2) & -.763 & .192 & 15.862 & 1 & .000 & .466 \\
\hline & Major(3) & -.218 & .210 & 1.081 & 1 & .298 & .804 \\
\hline & Major(4) & -.077 & .228 & .115 & 1 & .734 & .925 \\
\hline & Major(5) & -.548 & .190 & 8.354 & 1 & .004 & .578 \\
\hline & Major(6) & -.387 & .254 & 2.334 & 1 & .127 & .679 \\
\hline & Constant & -3.257 & .393 & 68.680 & 1 & .000 & .039 \\
\hline
\end{tabular}




\subsubsection{Model 4: College Academic Factors}

College academic factors including first-year GPA and number of first-year credit hours earned in college are added to the fourth model. These factors play a paramount role in a student's academic success. The details can be seen in Table 9. Both the first-year GPA and the number of credit hours earned are significant for both groups, and add the most explanatory power to the overall models. The pseudo-R-squares $(0.279$ and 0.257 , respectively) increase by $262 \%$ and $213 \%$. It means that, after controlling for other factors, for every one-unit increase in the first-year GPA, the likelihood of graduating from college increases significantly (by 3.739 and 4.086 times, respectively). The same occurs when considering the number of first-year credit hours earned. For every one-unit increase in the number of credit hours earned, the likelihood of graduating from college also increases. This is consistent with previous research that showed the significant relationship between college GPA and attrition (Miller, 1991).

This model is consistent with the previous statement that high school performance only accounts for a minimal amount of variance on college performance (Kuh et al., 2008; Wolfe \& Johnson, 1995). When first-year GPA and the number of first-year credit hours earned are added to the model, contrary to the previous models, the likelihood of graduating from college changes regarding high school GPA. Collinearity was examined with high school GPA as the dependent variable and ACT math score, first-year GPA, and first-year credit hours earned as the independent variables. Since the VIF values for all of the independent variables in both cohort groups are less than 2.0, collinearity problems were not present.

Table 8. Model 4 Summary

\begin{tabular}{ccccc}
\hline ENTRY_TERM & Step & $\begin{array}{c}-2 \text { Log } \\
\text { likelihood }\end{array}$ & $\begin{array}{c}\text { Cox \& Snell R } \\
\text { Square }\end{array}$ & $\begin{array}{c}\text { Nagelkerke R } \\
\text { Square }\end{array}$ \\
\hline 2009 & 1 & 2401.012 & .279 & .392 \\
2010 & 1 & 2935.461 & .257 & .363 \\
\hline
\end{tabular}


Table 9. College Academic Factors

\begin{tabular}{|c|c|c|c|c|c|c|c|}
\hline \multicolumn{2}{|c|}{ ENTRY_TERM } & & \multirow{2}{*}{$\begin{array}{l}\text { S.E. } \\
.113\end{array}$} & \multirow{2}{*}{$\frac{\text { Wald }}{1.358}$} & \multirow{2}{*}{$\begin{array}{l}\mathrm{df} \\
1\end{array}$} & \multirow{2}{*}{$\begin{array}{l}\text { Sig. } \\
.244\end{array}$} & \multirow{2}{*}{$\begin{array}{l}\operatorname{Exp}(B) \\
.876\end{array}$} \\
\hline & FIRST_GE0_FLAG & & & & & & \\
\hline & White_OtherThree & -.364 & .157 & 5.393 & 1 & .020 & .695 \\
\hline & GENDER & -.006 & .114 & .003 & 1 & .956 & .994 \\
\hline & HS_ACAD_AVG & -.415 & .160 & 6.747 & 1 & .009 & .660 \\
\hline & ACT_MATH & -.015 & .008 & 3.594 & 1 & .058 & .985 \\
\hline & Major & & & 24.078 & 6 & .001 & \\
\hline & Major(1) & -.882 & .230 & 14.776 & 1 & .000 & .414 \\
\hline \multirow[t]{15}{*}{2009} & Major(2) & -.680 & .242 & 7.871 & 1 & .005 & .507 \\
\hline & Major(3) & -.291 & .255 & 1.302 & 1 & .254 & .748 \\
\hline & Major(4) & -.424 & .273 & 2.412 & 1 & .120 & .655 \\
\hline & Major(5) & -.490 & .240 & 4.170 & 1 & .041 & .613 \\
\hline & Major(6) & -.287 & .285 & 1.019 & 1 & .313 & .750 \\
\hline & YR1_LAST_CUM_GPA & 1.319 & .105 & 156.486 & 1 & .000 & 3.739 \\
\hline & YR1_LAST_CREDITS & .060 & .008 & 64.137 & 1 & .000 & 1.062 \\
\hline & Constant & -2.059 & .506 & 16.580 & 1 & .000 & .128 \\
\hline & FIRST_GE0_FLAG & -.309 & .108 & 8.102 & 1 & .004 & .734 \\
\hline & White_OtherThree & .276 & .137 & 4.051 & 1 & .044 & 1.318 \\
\hline & GENDER & .093 & .099 & .884 & 1 & .347 & 1.097 \\
\hline & HS_ACAD_AVG & -.367 & .141 & 6.778 & 1 & .009 & .693 \\
\hline & ACT_MATH & .004 & .006 & .414 & 1 & .520 & 1.004 \\
\hline & Major & & & 52.322 & 6 & .000 & \\
\hline & Major(1) & -.861 & .211 & 16.601 & 1 & .000 & .423 \\
\hline \multirow[t]{8}{*}{2010} & Major(2) & -.516 & .216 & 5.716 & 1 & .017 & .597 \\
\hline & Major(3) & .120 & .235 & .262 & 1 & .609 & 1.128 \\
\hline & Major(4) & .100 & .256 & .152 & 1 & .697 & 1.105 \\
\hline & Major(5) & -.554 & .213 & 6.773 & 1 & .009 & .574 \\
\hline & Major(6) & -.538 & .281 & 3.662 & 1 & .056 & .584 \\
\hline & YR1_LAST_CUM_GPA & 1.408 & .096 & 214.826 & 1 & .000 & 4.086 \\
\hline & YR1_LAST_CREDITS & .042 & .006 & 50.223 & 1 & .000 & 1.043 \\
\hline & Constant & -3.114 & .450 & 47.965 & 1 & .000 & .044 \\
\hline
\end{tabular}

\subsubsection{Model 5: Home Address}

Student's home address, in-state or out-of-state, is included in the fifth model. This model also adds explanatory power to the overall model with a tiny increase in pseudo-R-square of only $0.3 \%$ and $2.7 \%$ (R-squares equal 0.280 , and 0.264 respectively). The home address is statistically significant for both groups. The details can be seen in Table 11. After controlling for other factors, for the two groups, the likelihood of graduating from college for a student with an in-state home address is 1.301 and 1.925 times higher than that of a student with an out-of-state home address. This finding indicates that students who attend college closer to home are more likely to graduate. 
Table 10. Model 5 Summary

\begin{tabular}{ccccc}
\hline \multirow{2}{*}{ ENTRY_TERM } & Step & $\begin{array}{c}-2 \text { Log } \\
\text { likelihood }\end{array}$ & $\begin{array}{c}\text { Cox \& Snell } \\
\text { R Square }\end{array}$ & $\begin{array}{c}\text { Nagelkerke R } \\
\text { Square }\end{array}$ \\
\hline 2009 & 1 & 2387.863 & .280 & .393 \\
2010 & 1 & 2888.882 & .264 & .373 \\
\hline
\end{tabular}

Table 11. Home Address

\begin{tabular}{|c|c|c|c|c|c|c|c|}
\hline \multicolumn{2}{|c|}{ ENTRY_TERM } & \multirow{2}{*}{$\begin{array}{l}\mathrm{B} \\
-.144\end{array}$} & \multirow{2}{*}{$\begin{array}{l}\text { S.E. } \\
.114\end{array}$} & \multirow{2}{*}{$\begin{array}{l}\text { Wald } \\
1.576\end{array}$} & \multirow{2}{*}{$\frac{\mathrm{df}}{1}$} & \multirow{2}{*}{$\begin{array}{l}\text { Sig. } \\
.209\end{array}$} & \multirow{2}{*}{$\begin{array}{l}\operatorname{Exp}(\mathrm{B}) \\
.866\end{array}$} \\
\hline \multirow{16}{*}{2009} & FIRST_GE0_FLAG & & & & & & \\
\hline & White_OtherThree & -.361 & .158 & 5.229 & 1 & .022 & .697 \\
\hline & GENDER & .007 & .114 & .004 & 1 & .950 & 1.007 \\
\hline & HS_ACAD_AVG & -.435 & .161 & 7.318 & 1 & .007 & .647 \\
\hline & ACT_MATH & -.019 & .008 & 5.251 & 1 & .022 & .981 \\
\hline & Major & & & 25.624 & 6 & .000 & \\
\hline & Major(1) & -.896 & .230 & 15.196 & 1 & .000 & .408 \\
\hline & Major(2) & -.665 & .243 & 7.500 & 1 & .006 & .514 \\
\hline & Major(3) & -.275 & .255 & 1.162 & 1 & .281 & .760 \\
\hline & Major(4) & -.411 & .274 & 2.261 & 1 & .133 & .663 \\
\hline & Major(5) & -.473 & .240 & 3.868 & 1 & .049 & .623 \\
\hline & Major(6) & -.260 & .286 & .828 & 1 & .363 & .771 \\
\hline & YR1_LAST_CUM_GPA & 1.304 & .106 & 151.871 & 1 & .000 & 3.685 \\
\hline & YR1_LAST_CREDITS & .063 & .008 & 67.701 & 1 & .000 & 1.065 \\
\hline & ADDR_STATE & .263 & .147 & 3.196 & 1 & .074 & 1.301 \\
\hline & Constant & -2.177 & .513 & 18.043 & 1 & .000 & .113 \\
\hline \multirow{16}{*}{2010} & FIRST_GE0_FLAG & -.365 & .110 & 10.987 & 1 & .001 & .695 \\
\hline & White_OtherThree & .259 & .139 & 3.456 & 1 & .063 & 1.295 \\
\hline & GENDER & .064 & .100 & .407 & 1 & .524 & 1.066 \\
\hline & HS_ACAD_AVG & -.417 & .143 & 8.509 & 1 & .004 & .659 \\
\hline & ACT_MATH & -.007 & .007 & .918 & 1 & .338 & .993 \\
\hline & Major & & & 56.885 & 6 & .000 & \\
\hline & Major(1) & -.904 & .214 & 17.920 & 1 & .000 & .405 \\
\hline & Major(2) & -.540 & .218 & 6.122 & 1 & .013 & .583 \\
\hline & Major(3) & .148 & .237 & .387 & 1 & .534 & 1.159 \\
\hline & Major(4) & .097 & .258 & .142 & 1 & .706 & 1.102 \\
\hline & Major(5) & -.568 & .215 & 6.968 & 1 & .008 & .567 \\
\hline & Major(6) & -.554 & .285 & 3.785 & 1 & .052 & .575 \\
\hline & YR1_LAST_CUM_GPA & 1.424 & .097 & 213.717 & 1 & .000 & 4.152 \\
\hline & YR1_LAST_CREDITS & .046 & .006 & 57.229 & 1 & .000 & 1.047 \\
\hline & ADDR_STATE & .655 & .122 & 28.988 & 1 & .000 & 1.925 \\
\hline & Constant & -3.336 & .456 & 53.455 & 1 & .000 & .036 \\
\hline
\end{tabular}




\subsubsection{Model 6: Learning Support}

Two learning support, academic services, tutoring (TU) and Supplemental Instruction (SI), offered by State University's learning center are included in the last model. These factors add considerable explanatory power to the overall models with an increase in pseudo-R-square of $12.5 \%$ and $10.6 \%$ (R-squares $=0.315$ and 0.292 , respectively). The academic service of SI is significant for both groups, and the academic service of TU is only significant for the 2009 group. The details can be seen in Table 13.

After controlling for other factors, when both the TU and SI services are added to the model, the likelihood of graduating from college for students who receive tutoring is 1.314 and 0.993 times higher than those who do not. Regarding SI, the likelihood of graduating from college for students participating in SI is 4.670 and 3.517 times higher than those who do not participate in SI, indicating that learning support is beneficial in helping students graduate in a timely manner.

Table 12. Model 6 Summary

\begin{tabular}{ccccc}
\hline ENTRY_TERM & Step & $\begin{array}{c}-2 \text { Log } \\
\text { likelihood }\end{array}$ & $\begin{array}{c}\text { Cox \& Snell R } \\
\text { Square }\end{array}$ & $\begin{array}{c}\text { Nagelkerke R } \\
\text { Square }\end{array}$ \\
\hline 2009 & 1 & 2258.402 & .315 & .442 \\
2010 & 1 & 2768.384 & .292 & .413 \\
\hline
\end{tabular}


Table 13. Learning Support

\begin{tabular}{|c|c|c|c|c|c|c|c|}
\hline \multicolumn{2}{|c|}{ ENTRY_TERM } & \multirow{2}{*}{$\begin{array}{l}\mathrm{B} \\
-.180\end{array}$} & \multirow{2}{*}{$\begin{array}{l}\text { S.E. } \\
.119\end{array}$} & \multirow{2}{*}{$\begin{array}{l}\text { Wald } \\
2.310\end{array}$} & \multirow{2}{*}{$\begin{array}{l}\mathrm{df} \\
1\end{array}$} & \multirow{2}{*}{$\begin{array}{l}\text { Sig. } \\
.129\end{array}$} & \multirow{2}{*}{$\begin{array}{l}\operatorname{Exp}(\mathrm{B}) \\
.835\end{array}$} \\
\hline \multirow{18}{*}{2009} & FIRST_GE0_FLAG & & & & & & \\
\hline & White_OtherThree & -.188 & .165 & 1.294 & 1 & .255 & .829 \\
\hline & GENDER & .031 & .118 & .068 & 1 & .794 & 1.031 \\
\hline & HS_ACAD_AVG & -.492 & .166 & 8.791 & 1 & .003 & .611 \\
\hline & ACT_MATH & -.019 & .008 & 4.934 & 1 & .026 & .981 \\
\hline & Major & & & 64.151 & 6 & .000 & \\
\hline & Major(1) & -1.408 & .235 & 35.838 & 1 & .000 & .245 \\
\hline & Major(2) & -1.238 & .251 & 24.384 & 1 & .000 & .290 \\
\hline & Major(3) & -.427 & .254 & 2.832 & 1 & .092 & .653 \\
\hline & Major(4) & -.644 & .276 & 5.454 & 1 & .020 & .525 \\
\hline & Major(5) & -.555 & .239 & 5.403 & 1 & .020 & .574 \\
\hline & Major(6) & -.357 & .284 & 1.573 & 1 & .210 & .700 \\
\hline & YR1_LAST_CUM_GPA & 1.160 & .109 & 113.081 & 1 & .000 & 3.190 \\
\hline & YR1_LAST_CREDITS & .065 & .008 & 67.994 & 1 & .000 & 1.067 \\
\hline & ADDR_STATE & .225 & .151 & 2.218 & 1 & .136 & 1.252 \\
\hline & SI & 1.541 & .167 & 85.576 & 1 & .000 & 4.670 \\
\hline & TU & .273 & .136 & 4.043 & 1 & .044 & 1.314 \\
\hline & Constant & -1.826 & .526 & 12.049 & 1 & .001 & .161 \\
\hline \multirow{18}{*}{2010} & FIRST_GE0_FLAG & -.331 & .113 & 8.590 & 1 & .003 & .718 \\
\hline & White_OtherThree & .435 & .144 & 9.108 & 1 & .003 & 1.545 \\
\hline & GENDER & .098 & .103 & .901 & 1 & .342 & 1.103 \\
\hline & HS_ACAD_AVG & -.449 & .146 & 9.391 & 1 & .002 & .638 \\
\hline & ACT_MATH & -.007 & .007 & .894 & 1 & .345 & .993 \\
\hline & Major & & & 91.119 & 6 & .000 & \\
\hline & Major(1) & -1.384 & .221 & 39.313 & 1 & .000 & .251 \\
\hline & Major(2) & -.990 & .225 & 19.418 & 1 & .000 & .372 \\
\hline & Major(3) & .014 & .238 & .003 & 1 & .954 & 1.014 \\
\hline & Major(4) & -.161 & .261 & .379 & 1 & .538 & .852 \\
\hline & Major(5) & -.592 & .215 & 7.600 & 1 & .006 & .553 \\
\hline & Major(6) & -.603 & .285 & 4.477 & 1 & .034 & .547 \\
\hline & YR1_LAST_CUM_GPA & 1.308 & .100 & 170.232 & 1 & .000 & 3.698 \\
\hline & YR1_LAST_CREDITS & .046 & .006 & 58.152 & 1 & .000 & 1.047 \\
\hline & ADDR_STATE & .606 & .125 & 23.535 & 1 & .000 & 1.834 \\
\hline & SI & 1.258 & .123 & 104.691 & 1 & .000 & 3.517 \\
\hline & TU & -.008 & .112 & .004 & 1 & .947 & .993 \\
\hline & Constant & -3.168 & .466 & 46.325 & 1 & .000 & .042 \\
\hline
\end{tabular}

\section{Discussion}

The purpose of this study was to determine which variables significantly help predict the likelihood of graduating from college within six years. Results reveal some interesting findings. These findings provide valuable information to the literature about the likelihood of graduating from college and college graduation rates. 
There are three important findings from this study. The first result of this study indicates that a student's home address plays a significant role in the likelihood of graduating from college. For both groups, students with in-state home addresses are about two times more likely to graduate than students with out-of-state home addresses. Therefore, institutions may consider targeting support and/or programs to out-of-state students in order to help them transition and connect to the university and persist to graduation.

Next, it is incomplete to compare likelihood of graduation without considering college major, since the likelihoods are significantly different among different majors. In this study, the likelihood of graduation is highest for communications and lowest for science and engineering. This indicates that students majoring in STEM disciplines are less likely to graduate and institutions may consider targeted efforts to help STEM students earn their degrees. But, other factors may influence these findings, such as GPA requirements for select majors.

Finally, a student's use of learning support, in this case academic support such as tutoring and Supplemental Instruction, increases the likelihood of college graduation. Evidence shows that students who participate in learning support resources are more likely to graduate, as those participating in Supplemental Instruction are four times more likely to graduate than students who do not participate, and those using tutoring are also more likely to graduate. This suggests that quality academic support programs help students persist to timely graduation. Therefore, institutions may consider substantial support and investment in quality learning support and academic resources.

Although this study uses a big sample size ( $\mathrm{N}=4241$, and $\mathrm{N}=4018)$, and two cohort groups, limitations still exist in at least four areas. First, participants were drawn from a single institution; therefore, these conclusions may not generalize to other institutional settings. In addition, these two groups (2009 and 2010 cohorts) were examined because this was the only data available for the period range of six years. Moreover, although the integrative persistence models were conducted for both groups, the results were not identically consistent, and without further information or analysis, there is no evidence to identify which group is more accurate at the present time. Finally, many additional demographic, pre-college, and college variables are cited in the literature and/or may play a role in helping students to earn their degrees, but they are not included in this study. Future examinations of the data may include such variables as family income, parents' educational background, college financial support and performance in gateway, introductory college courses for predicting college completion.

\section{References}

Attewell, P., Heil, S., \& Reisel, L. (2011). Competing Explanations of Undergraduate Noncompletion. American Educational Research Journal, 48(3), 536-559. https://doi.org/10.3102/0002831210392018

Breland, H., Maxey, J., Gernand, R., Cumming, T., \& Trapani, C. (2002). Trends in college admission 2000: A report of a national survey of undergraduate admission policies, practices, and procedures. Retrieved May, 13, 2002.

DeBerard, M. S., Spielmans, G., \& Julka, D. (2004). Predictors of academic achievement and retention among college freshmen: A longitudinal study. College Student Journal, 38(1), 66-80.

Fischer, M. J. (2007). Settling into campus life: Differences by race/ethnicity in college involvement and outcomes. Journal of Higher Education, 78(2), 125-161. https://doi.org/10.1353/jhe.2007.0009

Flashman, J. (2013). A cohort perspective on gender gaps in college attendance and completion. Research in Higher Education, 54(5), 545-570. https://doi.org/10.1007/s11162-013-9285-8

Flores, S. M., \& Park, T. J. (2013). Race, ethnicity, and college success examining the continued significance of the minority-serving institution. Educational Researcher, $42(3), \quad$ 115-128. https://doi.org/10.3102/0013189X13478978

Habley, W. R., \& McClanahan, R. (2004). What Works in Student Retention? Four-Uear Public Colleges. ACT, Inc.

Institute for Higher Education Policy (US)(IHEP). (2012). Supporting first-generation college students through classroom-based practices.

Ishitani, T. T. (2006). Studying attrition and degree completion behavior among first-generation college students in the United States. Journal of Higher Education, 77(5), 861-885. https://doi.org/10.1353/jhe.2006.0042

John, E. P., Cabrera, A. F., Nora, A., \& Asker, E. H. (2000). Economic influences on persistence reconsidered. Reworking the student departure puzzle, 29-47. 
Kuh, G. D., Cruce, T. M., Shoup, R., Kinzie, J., \& Gonyea, R. M. (2008). Unmasking the effects of student engagement on first-year college grades and persistence. The Journal of Higher Education, 79(5), 540-563. https://doi.org/10.1353/jhe.0.0019

Mattern, K. D., \& Marini, J. (2014). Does College Readiness Translate to College Completion? New York: The College Board. Retrieved from https://research.collegeboard.org/sites/default/files/publications/2014/1/research-note-2013-9-college-readinesscollege-completion.pdf

Mettler, S. (2011). Redirecting and expanding support for college students. In T. Skocpol \& L. Jacobs (Eds.), Reaching for a new deal: Ambitious governance, economic meltdown, and polarized politics in Obama's first two years. New York, NY: Russell Sage Foundation.

Miller, R. J. (1991). Persistence in higher education: A review of the literature for continuing educators. The Journal of Continuing Higher Education, 39(1), 19-22. https://doi.org/10.1080/07377366.1991.10400804

Perna, L. W. (1998). The contribution of financial aid to undergraduate persistence. Journal of Student Financial Aid, 28(3), 25-40.

Petty, T. (2014). Motivating first-generation students to academic success and college completion. College Student Journal, 48(2), 257-264.

Radunzel, J., \& Noble, J. (2012). Predicting Long-Term College Success through Degree Completion Using ACT [R] Composite Score, ACT Benchmarks, and High School Grade Point Average. ACT Research Report Series, 2012(5). ACT, Inc.

Reason, R. (2003). Student variables that predict retention: Recent research and new developments. NASPA Journal, 40(4), 172-191. https://doi.org/10.2202/1949-6605.1286

Richardson Jr, R. C., \& de los Santos Jr, A. G. (1988). Helping Minority Students Graduate from College--A Comprehensive Approach. ERIC Digest.

Tinto, V. (1975). Dropout from higher education: A theoretical synthesis of recent research. Review of Educational Research, 45(1), 89-125. https://doi.org/10.3102/00346543045001089

Wagner, J. M. (2015). Hispanic minority college students at selective colleges: What matters with degree completion?. Journal of Hispanic Higher Education, 14(4), 303-326. https://doi.org/10.1177/1538192714568807

Wolfe, R. N., \& Johnson, S. D. (1995). Personality as a predictor of college performance. Educational and Psychological Measurement, 55(2), 177-185. https://doi.org/10.1177/0013164495055002002

Zwick, R., \& Sklar, J. C. (2005). Predicting college grades and degree completion using high school grades and SAT scores: The role of student ethnicity and first language. American Educational Research Journal, 42(3), 439-464. https://doi.org/10.3102/00028312042003439 


\section{Appendix}

Table 14. Model 1 Classification Table ${ }^{\mathrm{a}}$

\begin{tabular}{|c|c|c|c|c|c|c|}
\hline \multirow{3}{*}{\multicolumn{2}{|c|}{ ENTRY_TERM }} & \multirow{3}{*}{\multicolumn{2}{|c|}{ Observed }} & \multicolumn{3}{|c|}{ Predicted } \\
\hline & & & & \multicolumn{2}{|c|}{ LSUGRADYR6 } & \multirow{2}{*}{$\begin{array}{c}\text { Percentage } \\
\text { Correct }\end{array}$} \\
\hline & & & & 0 & 1 & \\
\hline \multirow{3}{*}{2009} & \multirow{3}{*}{ Step 1} & \multirow{2}{*}{ LSUGRADYR6 } & 0 & 0 & 1028 & .0 \\
\hline & & & 1 & 0 & 2070 & 100.0 \\
\hline & & \multicolumn{2}{|c|}{ Overall Percentage } & & & 66.8 \\
\hline \multirow{3}{*}{2010} & \multirow{3}{*}{ Step 1} & \multirow{2}{*}{ LSUGRADYR6 } & 0 & 34 & 1043 & 3.2 \\
\hline & & & 1 & 28 & 2242 & 98.8 \\
\hline & & \multicolumn{2}{|c|}{ Overall Percentage } & & & 68.0 \\
\hline
\end{tabular}

a. The cut value is .500

Table 15. Model 2 Classification Table ${ }^{\mathrm{a}}$

\begin{tabular}{|c|c|c|c|c|c|c|}
\hline \multirow{2}{*}{\multicolumn{2}{|c|}{ ENTRY_TERM }} & \multirow{3}{*}{\multicolumn{2}{|c|}{ Observed }} & \multicolumn{3}{|c|}{ Predicted } \\
\hline & & & & \multicolumn{2}{|c|}{ LSUGRADYR6 } & \multirow{2}{*}{$\begin{array}{c}\text { Percentage } \\
\text { Correct }\end{array}$} \\
\hline & & & & 0 & 1 & \\
\hline \multirow{3}{*}{2009} & \multirow{3}{*}{ Step 1} & \multirow{2}{*}{ LSUGRADYR6 } & 0 & 144 & 884 & 14.0 \\
\hline & & & 1 & 131 & 1937 & 93.7 \\
\hline & & \multicolumn{2}{|c|}{ Overall Percentage } & & & 67.2 \\
\hline \multirow{3}{*}{2010} & \multirow{3}{*}{ Step 1} & \multirow{2}{*}{ LSUGRADYR6 } & 0 & 144 & 932 & 13.4 \\
\hline & & & 1 & 138 & 2129 & 93.9 \\
\hline & & \multicolumn{2}{|c|}{ Overall Percentage } & & & 68.0 \\
\hline
\end{tabular}

a. The cut value is .500

Table 16. Model 3 Classification Table ${ }^{\mathrm{a}}$

\begin{tabular}{|c|c|c|c|c|c|c|}
\hline \multirow{2}{*}{\multicolumn{2}{|c|}{ ENTRY_TERM }} & \multirow{3}{*}{\multicolumn{2}{|c|}{ Observed }} & \multicolumn{3}{|c|}{ Predicted } \\
\hline & & & & \multicolumn{2}{|c|}{ LSUGRADYR6 } & \multirow{2}{*}{$\begin{array}{c}\text { Percentage } \\
\text { Correct }\end{array}$} \\
\hline & & & & 0 & 1 & \\
\hline \multirow{3}{*}{2009} & \multirow{3}{*}{ Step 1} & \multirow{2}{*}{ LSUGRADYR6 } & 0 & 146 & 688 & 17.5 \\
\hline & & & 1 & 124 & 1659 & 93.0 \\
\hline & & \multicolumn{2}{|c|}{ Overall Percentage } & & & 69.0 \\
\hline \multirow{3}{*}{2010} & \multirow{3}{*}{ Step 1} & \multirow{2}{*}{ LSUGRADYR6 } & 0 & 169 & 811 & 17.2 \\
\hline & & & 1 & 151 & 2032 & 93.1 \\
\hline & & \multicolumn{2}{|c|}{ Overall Percentage } & & & 69.6 \\
\hline
\end{tabular}

a. The cut value is .500 
Table 17. Model 4 Classification Table ${ }^{\mathrm{a}}$

\begin{tabular}{|c|c|c|c|c|c|c|}
\hline \multirow{3}{*}{\multicolumn{2}{|c|}{ ENTRY_TERM }} & \multirow{3}{*}{\multicolumn{2}{|c|}{ Observed }} & \multicolumn{3}{|c|}{ Predicted } \\
\hline & & & & \multicolumn{2}{|c|}{ LSUGRADYR6 } & \multirow{2}{*}{$\begin{array}{c}\text { Percentage } \\
\text { Correct }\end{array}$} \\
\hline & & & & 0 & 1 & \\
\hline \multirow{3}{*}{2009} & \multirow{3}{*}{ Step 1} & \multirow{2}{*}{ LSUGRADYR6 } & 0 & 419 & 406 & 50.8 \\
\hline & & & 1 & 145 & 1637 & 91.9 \\
\hline & & \multicolumn{2}{|c|}{ Overall Percentage } & & & 78.9 \\
\hline \multirow{3}{*}{2010} & \multirow{3}{*}{ Step 1} & \multirow{2}{*}{ LSUGRADYR6 } & 0 & 466 & 495 & 48.5 \\
\hline & & & 1 & 169 & 2012 & 92.3 \\
\hline & & \multicolumn{2}{|c|}{ Overall Percentage } & & & 78.9 \\
\hline
\end{tabular}

a. The cut value is .500

Table 18. Model 5 Classification Table ${ }^{a}$

\begin{tabular}{|c|c|c|c|c|c|c|}
\hline \multirow{3}{*}{\multicolumn{2}{|c|}{ ENTRY_TERM }} & \multirow{3}{*}{\multicolumn{2}{|c|}{ Observed }} & \multicolumn{3}{|c|}{ Predicted } \\
\hline & & & & \multicolumn{2}{|c|}{ LSUGRADYR6 } & \multirow{2}{*}{$\begin{array}{c}\text { Percentage } \\
\text { Correct }\end{array}$} \\
\hline & & & & 0 & 1 & \\
\hline \multirow{3}{*}{2009} & \multirow{3}{*}{ Step 1} & LSUGRADY & 0 & 417 & 403 & 50.9 \\
\hline & & R6 & 1 & 142 & 1637 & 92.0 \\
\hline & & \multicolumn{2}{|c|}{ Overall Percentage } & & & 79.0 \\
\hline \multirow{3}{*}{2010} & \multirow{3}{*}{ Step 1} & LSUGRADY & 0 & 466 & 488 & 48.8 \\
\hline & & R6 & 1 & 155 & 2021 & 92.9 \\
\hline & & \multicolumn{2}{|c|}{ Overall Percentage } & & & 79.5 \\
\hline
\end{tabular}

a. The cut value is .500

Table 19. Model 6 Classification Table ${ }^{a}$

\begin{tabular}{|c|c|c|c|c|c|c|}
\hline \multirow{3}{*}{\multicolumn{2}{|c|}{ ENTRY_TERM }} & \multirow{3}{*}{\multicolumn{2}{|c|}{ Observed }} & \multicolumn{3}{|c|}{ Predicted } \\
\hline & & & & \multicolumn{2}{|c|}{ LSUGRADYR6 } & \multirow{2}{*}{$\begin{array}{c}\text { Percentage } \\
\text { Correct }\end{array}$} \\
\hline & & & & 0 & 1 & \\
\hline \multirow{3}{*}{2009} & \multirow{3}{*}{ Step 1} & \multirow{2}{*}{ LSUGRADYR6 } & 0 & 449 & 371 & 54.8 \\
\hline & & & 1 & 153 & 1626 & 91.4 \\
\hline & & \multicolumn{2}{|c|}{ Overall Percentage } & & & 79.8 \\
\hline \multirow{3}{*}{2010} & \multirow{3}{*}{ Step 1} & \multirow{2}{*}{ LSUGRADYR6 } & 0 & 496 & 458 & 52.0 \\
\hline & & & 1 & 171 & 2005 & 92.1 \\
\hline & & \multicolumn{2}{|c|}{ Overall Percentage } & & & 79.9 \\
\hline
\end{tabular}

a. The cut value is .500 
Table 20. Parameter Coding

\begin{tabular}{lllllllll}
\hline \multicolumn{7}{c}{ Frequency } & \multicolumn{2}{l}{ Parameter coding } \\
& & $(1)$ & $(2)$ & $(3)$ & $(4)$ & $(5)$ & $(6)$ \\
\hline \multirow{4}{*}{ Major } & 1.00 & 704 & 1.000 & .000 & .000 & .000 & .000 & .000 \\
& 2.00 & 536 & .000 & 1.000 & .000 & .000 & .000 & .000 \\
& 3.00 & 299 & .000 & .000 & 1.000 & .000 & .000 & .000 \\
& 4.00 & 199 & .000 & .000 & .000 & 1.000 & .000 & .000 \\
& 5.00 & 474 & .000 & .000 & .000 & .000 & 1.000 & .000 \\
& 6.00 & 200 & .000 & .000 & .000 & .000 & .000 & 1.000 \\
& 7.00 & 205 & .000 & .000 & .000 & .000 & .000 & .000 \\
\hline
\end{tabular}

Table 21. High School GPA Based on Majors

\begin{tabular}{llll}
\hline ENTRY_TERM & N & Mean \\
\hline \multirow{6}{*}{2009} & 1.00 & 991 & 3.47 \\
& 2.00 & 752 & 3.41 \\
& 3.00 & 413 & 3.18 \\
& 4.00 & 257 & 3.35 \\
& 5.00 & 596 & 3.34 \\
& 6.00 & 264 & 3.36 \\
& 7.00 & 269 & 3.33 \\
& Total & 3542 & 3.37 \\
& & & \\
& 1.00 & 936 & 3.48 \\
& 2.00 & 863 & 3.38 \\
& 3.00 & 410 & 3.21 \\
& 4.00 & 290 & 3.33 \\
& 5.00 & 781 & 3.31 \\
& 6.00 & 191 & 3.36 \\
& 7.00 & 261 & 3.36 \\
& Total & 3732 & 3.36 \\
\hline
\end{tabular}

